\title{
Matrix Instruments for Calculating Costs of Concrete with Multicomponent Binders
}

\author{
T. Kuladzhi ${ }^{1(凶)}$, S.-A. Murtazaev ${ }^{2,3,4}$, S. Aliev², and M. Hubaev ${ }^{2}$ \\ ${ }^{1}$ Lomonosov North (Arctic) Federal University, Arkhangelsk, Russia \\ kuladzhit@list.ru \\ ${ }^{2}$ Millionshchikov Grozny State Oil Technical University, Grozny, Russia \\ ${ }^{3}$ Ibragimov Complex Research Institute, RAS, Grozny, Russia \\ ${ }^{4}$ Academy of Sciences of the Chechen Republic, Grozny, Russia
}

\begin{abstract}
The paper describes methodology for determining the costs of construction products - concrete with multicomponent binders, containing the matrix formula by Professor M.D. Kargopolov, which is recommended a modern micro-prediction tool for the production efficiency of building materials and products, allowing simultaneous calculations of their costs taking into account all the volumes of material costs: cement, fittling, components of binders, etc., as well as wage costs, depreciation etc.
\end{abstract}

Keywords: Concretes with multicomponent binders •

Solar thermal processing - Micro-prediction tools for production efficiency • Composite building materials $\cdot$ Matrix formula by professor M.D. Kargopolov

\section{Introduction}

Measures are taken in the building complex of Russia at the state level to improve the efficiency and the system for determining the costs of building products. The estimated cost of construction work includes: direct costs, overhead costs and estimated profit (The Civil Code... 1996; On approval... 2004; Taymaskhanov et al. 2012).

To ensure the effectiveness of the production of innovative products the matrix formula by Professor Kargopolov is recommended, providing transparency and accuracy of calculations of the costs of production, taking into account all the territorial conditions affecting the estimated cost of production (Kuladzhi 2014; Kargopolov 2001).

\section{Methods and Materials}

D.Sc.(Economics) Kargopolov in (Kargopolov 2001) showed that any economic system of economic entities can be represented as a scheme of interacting objects producing a specific product (as part of $\mathrm{X}$ ), from which part of the output - W in the studied economic system is used inside the system, and the other - (Y) as the final product is taken outside this system. Therefore, to assess the magnitude of costs and 
results of the effectiveness of each such product, the entire production process $\Pi$ of an organization can be represented by a general structure.

Matrix formula by Professor M.D. Kargopolov is given by:

$$
\mathrm{P}=(\mathrm{E}-\mathrm{AT})-1 * \mathrm{DT} * \mathrm{C}
$$

where: $\mathrm{P}=\left\|\mathrm{p}_{\mathrm{j}}\right\| ; \mathrm{j}=\overline{1, n}-$ desired column vector of production (full) cost per unit of production (works, services);

$\mathrm{E}-$ single matrix $\mathrm{n} \times \mathrm{n}$;

$\mathrm{A}=\left\|\mathrm{a}_{\mathrm{ij}}\right\|, \mathrm{i}=\overline{1, n}, \mathrm{j}=\overline{1, n}-$ matrix $\mathrm{n} \times \mathrm{n}$ of consumption rates of own production resources;

$\mathrm{D}=\left\|\mathrm{d}_{\mathrm{ij}}\right\|, \mathrm{i} \in \mathrm{L} \mathrm{U} \mathrm{R}, \mathrm{j}=\overline{1, n}$ - matrix of consumption rates of the primary resources ( $\mathrm{L}$ - variable, $\mathrm{R}$ - constant),

$\mathrm{T}$ - transposition mark for matrices $\mathrm{A}$ and $\mathrm{D}$.

$\mathrm{C}=\left\|\mathrm{c}_{\mathrm{i}}\right\|, \mathrm{i} \in \mathrm{L} \mathrm{U} \mathrm{R}$ - column vector of the wholesale and procurement prices of primary resources, and if resources are represented by value indicators in matrix $\mathrm{D}$, then in matrix $\mathrm{C}$ these resources, respectively, should be denoted by number -1 (one).

\section{Results and Discussion}

To calculate the total cost of production of reinforced concrete floor slabs using helioforms, we used actual data on labor costs and costs of materials for the manufacture of reinforced concrete floor slabs of type 10-60.12 under the conditions of Argun reinforced concrete products and structures (Table 1).

Thus, Table 1 presents matrix D in such a way that it consistently (from simple to complex products - a reinforced concrete slab) reveals indicators of the consumption of materials for:

- production of process water: 1 column;

- steam production: 2 column;

- production of complex binders (dry mix: cement, filler and additives "Bio-NM), made in the scientific laboratory of building department of the Grozny State Oil Technical University named after Academician M.D. Millionshchikov (Kargopolov 2001): 3, 4 columns

- production of components of concrete mixes (dry mix: complex binders - CB and crushing residue): 5-6 columns;

- production of $1 \mathrm{~m}^{3}$ of concrete products under solar thermal treatment: 7-8 columns. 
Table 1. Matrix D of consumption rates of primary resources, incl. purchased, for the production of reinforced concrete products and matrix $\mathrm{C}$ of wholesale procurement prices of primary resources

\begin{tabular}{|c|c|c|c|c|c|c|c|c|c|c|}
\hline \multirow[t]{2}{*}{ Costs } & \multirow[t]{2}{*}{ Water } & \multirow[t]{2}{*}{ Steam } & \multicolumn{2}{|c|}{$\begin{array}{l}\text { Binder } \\
\text { composition }\end{array}$} & \multicolumn{2}{|c|}{$\begin{array}{l}\text { Dry } \\
\text { concrete } \\
\text { mix }\end{array}$} & \multicolumn{2}{|c|}{$\begin{array}{l}\text { Reinforced } \\
\text { concrete products } \\
\text { with solar } \\
\text { thermal treatment }\end{array}$} & \multirow[t]{2}{*}{ № } & \multirow{2}{*}{\begin{tabular}{|l|} 
Matrix \\
C \\
Price
\end{tabular}} \\
\hline & & & $\begin{array}{l}K B \\
100\end{array}$ & KB3 50 & $\begin{array}{l}K B \\
100\end{array}$ & $\begin{array}{l}K B 3 \\
50\end{array}$ & KB 100 & KB3 50 & & \\
\hline $\begin{array}{l}\text { Capital investments in } \\
\text { helioforms (per } 1 \mathrm{~m}^{3} \text { of } \\
\text { reinforced concrete } \\
\text { products), thousand } \\
\text { rubles } / \mathrm{m}^{3}\end{array}$ & 0 & 0 & 0 & 0 & 0 & 0 & 0,012 & 0,012 & 1 & 0,012 \\
\hline $\begin{array}{l}\text { Cement, thousand } \\
\text { rubles/t }\end{array}$ & 0 & 0 & 0,5 & 0,254 & 0 & 0 & 0 & 0 & 2 & 5 \\
\hline $\begin{array}{l}\text { Crushing residue, } \\
\text { thousand rubles/t }\end{array}$ & 0 & 0 & 0 & 0 & 1,5 & 1,524 & 0 & 0 & - & 0,25 \\
\hline Filler, thousand rubles/t & 0 & 0 & 0 & 0,254 & 0 & 0 & 0 & 0 & 2 & 1,5 \\
\hline $\begin{array}{l}\text { BIO-NM additive, } \\
\text { thousand rubles/t }\end{array}$ & 0 & 0 & 0,01 & 0,00508 & 0 & 0 & 0 & 0 & 4 & 22 \\
\hline $\begin{array}{l}\text { Fitting, thousand } \\
\text { rubles/t }\end{array}$ & 0 & 0 & 0 & 0 & 0 & 0 & 0,065 & 0,065 & 5 & 5 \\
\hline Electricity and fuel & 0,0124 & 0,0414 & 0 & 0 & 0 & 0 & 0,2794 & 0,2794 & 6 & 1 \\
\hline $\begin{array}{l}\text { Water, thousand } \\
\text { rubles/t }\end{array}$ & 0,02365 & 0 & 0 & 0 & 0 & 0 & 0 & 0 & 7 & 1 \\
\hline $\begin{array}{l}\text { Wages, thousand } \\
\text { rubles }\end{array}$ & 0,01 & 0,025 & 0 & 0 & 0 & 0 & 0,3439 & 0,3439 & 8 & 1 \\
\hline $\begin{array}{l}\text { Equipment } \\
\text { maintenance costs } \\
\text { ( } 127.8 \% \text { of salary), } \\
\text { thousand rubles }\end{array}$ & 0,0128 & 0,032 & 0 & 0 & 0 & 0 & 0,4395 & 0,4395 & 9 & 1 \\
\hline $\begin{array}{l}\text { Shop expenses ( } 25 \% \text { of } \\
\text { salary), thousand } \\
\text { rubles }\end{array}$ & 0,0025 & 0,0064 & 0 & 0 & 0 & 0 & 0,086 & 0,086 & 10 & 1 \\
\hline $\begin{array}{l}* \text { Deduction for social } \\
\text { insurance }(34 \% \text { for } \\
2011 *) \text {, thousand } \\
\text { rubles }\end{array}$ & 0,0034 & 0,0085 & 0 & 0 & 0 & 0 & 0,1169 & 0,1169 & 11 & 1 \\
\hline $\begin{array}{l}\text { Plant costs }(20 \%) \text {, } \\
\text { thousand rubles }\end{array}$ & 0,002 & 0,005 & 0 & 0 & 0 & 0 & 0,06878 & 0,06878 & 12 & 1 \\
\hline Other, thousand rubles & 0,0137 & 0,05 & 0 & 0 & 0 & 0 & 0 & 0 & 13 & 1 \\
\hline
\end{tabular}

\section{Conclusions}

Considering that the balance equation of the Nobel Prize winner in economics V.V. Leontiev is a macro-prediction tool for output of products at the national and world levels, the matrix formula by Professor M.D. Kargopolov should be considered as an 
instrument for micro-prediction of cost indicators of products of any economic entities companies, households and other subjects, including products of cluster subjects.

\section{References}

Kargopolov MD (2001) Interoperable balances of costs and results of production: theory and practice. Monograph. Arkhangelsk: Publishing House of AGSTU, $182 \mathrm{p}$

Kuladzhi TV (2014) Methodology for evaluating the effectiveness of design solutions in the construction complex. North (Arctic) Federal University - Arkhangelsk: NAFU Publishing House, $296 \mathrm{p}$

On approval and implementation of the Methodology for determining the cost of construction products in the territory of the Russian Federation (together with "MDS 81-35.2004 ..."). Resolution of the State Construction Committee of Russia of 05.03.2004 No. 15/1 (as amended on 06.16.2014)

Taymaskhanov KE, Bataev DK-S, Murtazaev S-AY, Saidumov MS (2012) Justification of the economic efficiency of the production of concrete composites based on technogenic raw materials. Questions Econ Law 2:124-128

The Civil Code of the Russian Federation (part two) dated January 26, 1996 No. 14-FZ (as amended on July 29, 2017) (as amended and added, entered into force on December 30, 2018)

Open Access This chapter is licensed under the terms of the Creative Commons Attribution 4.0 International License (http://creativecommons.org/licenses/by/4.0/), which permits use, sharing, adaptation, distribution and reproduction in any medium or format, as long as you give appropriate credit to the original author(s) and the source, provide a link to the Creative Commons license and indicate if changes were made.

The images or other third party material in this chapter are included in the chapter's Creative Commons license, unless indicated otherwise in a credit line to the material. If material is not included in the chapter's Creative Commons license and your intended use is not permitted by statutory regulation or exceeds the permitted use, you will need to obtain permission directly from the copyright holder.

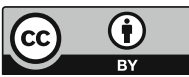

